\title{
PENGARUH PEMBERIAN BUAH NAGA TERHADAP PENINGKATAN KADAR HEMOGLOBIN PADA IBU HAMIL DI PUSKESMAS SINDANG JAYA KABUPATEN TANGERANG
}

\author{
${ }^{1}$ Ratumas Ratih Puspita, ${ }^{2}$ Indah Pratiwi \\ 1,2 Pogram Studi S1 Keperawatan, STIKes Widya Dharma Husada Tangerang \\ ${ }^{1}$ Email: ratumas.rp@gmail.com
}

\begin{abstract}
ABSTRAK
Pendahuluan, Anemia pada kehamilan merupakan anemia kekurangan zat besi, anemia defisiensi besi pada wanita hamil merupakan problem kesehatan (WHO,2009). Menurut Riskesdas (2018) secara nasional, penduduk Indonesia terdapat angka kehamilan penduduk perempuan usia 15-49 tahun 20,7\%, terdapat kehamilan umur kurang 15 tahun 0,02\% sedangkan kehamilan pada umur 15-19 tahun sebesar 38,5\%.Metode Penelitian, merupakan penelitian preeksperimen dan memakai metode one grup pretest tanpa menggunakan kelompok perbandingan untuk mengetahui hubungan antara variabel independen dengan variabel dependen, data yang dikumpulkan dengan menggunakan metode pretest. Jumlah sampel sebanyak 10 orang ibu hamil di puskesmas sindang jaya Hasil penelitian dan pembahasan, dari 10 responden didapatkan hasil bahwa ibu hamil yang memiliki anemia rendah sebanyak 30\% dan ibu hamil yang memiliki Hemoglobin normal sebanyak $70 \%$ ibu hamil didapatkan hasil p-value $0,005(\mathrm{p}<0,05)$ dan dapat disimpulkan bahwa ada pengaruh pemberian buah naga terhadap peningkatan kadar hemoglobin pada ibu hamil di puskesmas sindang jaya.Kesimpulan, diharapkan untuk mengkonsumsi vitamin agar ibu dan bayi yang berada di dalam kandungan menjadi sehat, terutama pada ibu hamil di Puskesmas Sindang Jaya.
\end{abstract}

Kata kunci: ibu hamil, kadar Hemoglobin rendah

\begin{abstract}
Introduction, Anemia in pregnancy is an iron deficiency anemia, iron deficiency anemia in pregnant women is a health problem (WHO, 2009). According to Riskesdas (2018) nationally, the population of Indonesia has a pregnancy rate of women aged 15-49 years 20.7\%, there are pregnancies of less than 15 years of age $0.02 \%$ while pregnancies at the age of 15-19 years are 38.5\%.Research method, is a experimental study and uses the one group pretest method without using a comparison group to find out the relationship between independent variables and dependent variables, data collected using the pretest method. The number of samples of 10 pregnant women in the puskesmas sindang jaya The results of the study and discussion, from 10 respondents, showed that pregnant women who had anemia were as low as $30 \%$ and pregnant women who had normal hemoglobin as much as $70 \%$ of pregnant women obtained p-value $0.005(p<0.05)$ and it can be concluded that there is an effect of giving dragon fruit to the increase of hemoglobin levels in pregnant women in pusang sindang jaya. Conclusion, it is expected to take vitamins so that mothers and babies in the womb become healthy, especially in pregnant women in Sindang Jaya Health Center.
\end{abstract}

Keywords: pregnant women, low hemoglobin levels. 


\section{PENDAHULUAN}

Anemia pada kehamilan merupakan anemia karena kekurangan zat besi, anemia defisiensi besi pada wanita hamil merupakan problema kesehatan yang dialami oleh wanita diseluruh dunia terutama dinegara berkembang. Badan kesehatan dunia (World Health Organization $=$ WHO,2009) melaporkan bahwa ibu-ibu hamil yang mengalami defisiensi besi sekitar 35-75\% serta semakin meningkat seiring dengan bertambahnya usiakehamilan. Menurut WHO 40\% kematian ibu dinegara berkembang berkaitan dengan anemia pada kehamilan disebabkan oleh defisiensi besi dan perdarahan akut. Hasil persalinan pada wanita hamil yang menderita anemia defisiensi besi adalah 12-28\% angka kematian janin, $30 \%$ kematian perinatal dan 7-10\% angka kematian neonatal (Proverawati, dkk,2010, Anggeraini,2018).

Berdasarkan hasil survei data Demografi dan kesehatan Indonesia (SDKI) pada tahun 2012, angka kematian ibu di Indonesia masih tinggi sebesar 359 per 100.000 kelahiran hidup Angka ini sedikit menurun jika dibandingkan dengan (SDKI) pada tahun 1991 kelahiran hidup Angka ini sedikit menurun meskipun tidak terlalu signifikan dengan hasil sebesar 390 per 100.000. Target global MDGs (Millienium Development Goals) adalah menurunnya angka kematian ibu mencapai 102 per 100.000 kelahiran hidup pada tahun 2015 (Departemen Kesehatan, 2015).

\section{METODE}

Desain penelitian adalah modul atau metode yang digunakan peneliti untuk melakukan suatu penelitian yang memberikan arahan terhadap jalan nya penelitian (Dharma,2011). Penelitian ini menggunakan preeksperimen dalam kelompok Experimental berupa percobaan/perlakuan yang bertujuan untuk mengetahui suatu gejala atau pengaruh yang timbul sebagai akibat dari adanya perlakuan tertentu terhadap suatu subjek yang mendapat perlakuan. Dari perlakuan tersebut diharapkan terjadi perubahan dari subjek yang diamati (Notoatmojo,2012). Desain penelitian ini menggunakan one grup pretest posttest tanpa menggunakan kelompok pendamping (kontrol).

\section{SAMPEL}

Sampel merupakan bagian dari jumlah dan karakteristik yang dimiliki oleh populasi. Bila populasi besar, dan penelitian tidak mungkin mempelajari semua yang ada pada populasi, misalnya karena keterbatasan dana, tenaga dan waktu, maka peneliti dapat menggunakan sampel yang diambil dari populasi itu. Apa yang dipelajari dari sampel, kesimpulanya akan dapat diberikan untuk populasi. Untuk itu 
sampel yang diambil dari populasi harus betul-betul representative atau mewakili (Sugiono,2014).

Pengambilan sampel pada penelitian ini menggunakan metode nonprobability sampling dimana tehnik pengambilan sampel yang tidak memberi peluang atau kesempatan sama bagi setiap unsur atau anggota populasi untuk dipilih menjadi sampel. Dengan teknik purposive sampling yaitu pengambilan sampel dengan satu pertimbangan tertentu (Sugiono,2014).

\section{Instrument pengumpulan data}

a. Alat Mission $\mathrm{Hb}$

\section{HASIL}

\section{1) Usia Ibu Hamil}

Diagram 5.1Distribusi Frekuensi RespondenBerdasarkan Usia Ibu Hamil DiPuskesmas Sindang Jaya Kabupaten Tangerang $(n=10)$

usia ibu hamil

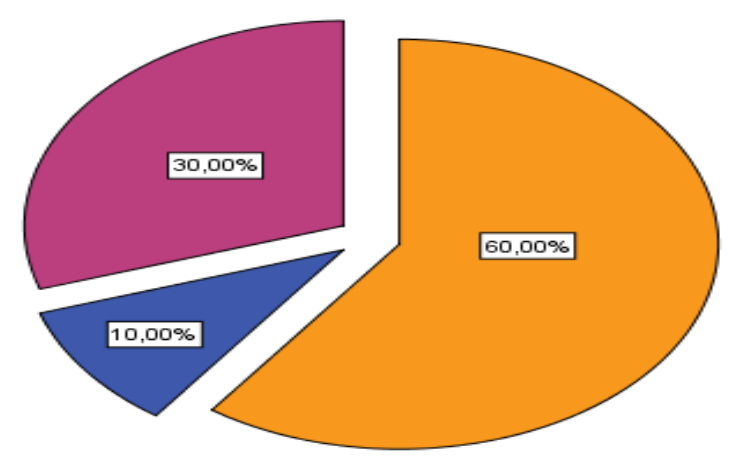

Berdasarkan diagram 5.1 distribusi diatas 23-27 tahun sebanyak 3 orang frekuensi responden berdasarkan usia (30\%) dan responden yang berusia 33dari 10 responden didapatkan hasil 37 tahub sebanyak 1 orang $(10 \%)$.
Mission $\mathrm{Hb}$ adalah alat yang digunakan untuk mengukur kadar hemoglobin.

b. Timbangan Digital

Timbangan adalah alat yang digunakan untuk menimbang buah naga dengan satuan berbentuk gram.

\section{c. Lembar Observasi}

Lembar observasi digunakan untuk mencatat karakteristik responden yang meliputi nomor responden, nama responden, usia dan jenis kelamin. Data digunakan juga untuk mencatat pengukuran kadar hemoglobin sebelum dan sesudah intervensi. sebanyak 6 orang $(60 \%)$ memiliki usia 18-22 tahun responden yang berusia 


\section{2) Usia Kehamilan}

Diagram 5.2. Distribusi Frekuensi Responden Berdasarkan Usia Ibu Hamil Di Wilayah Kerja Puskesmas Sindang Jaya Kabupaten Tangerang $(n=10)$

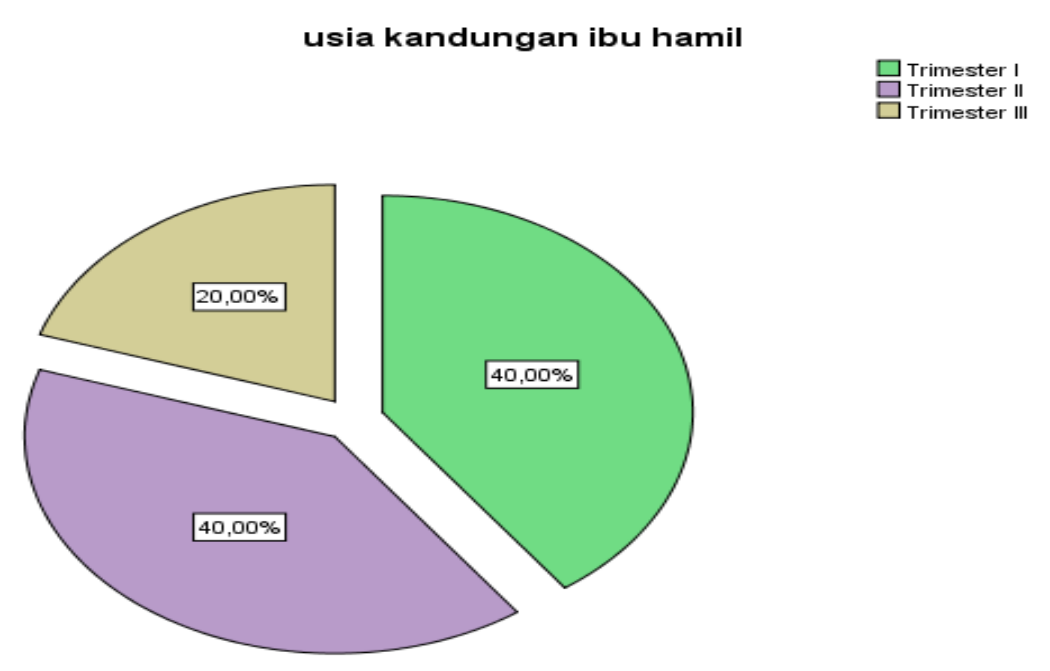

Berdasarkan diagram 5.2 distribusi trimester I, responden yang berusia frekuensi responden berdasarkan usia kehamilan trimester II sebanyak 4 kehamilan dari 10 responden orang $(40 \%)$, dan responden yang didapatkan hasin sebanyak 4 orang berusia kehamilan trimester III (40\%) merupakan usia kehamilan sebanyak 2 orang $(20 \%)$.

\section{3) Pendidikan Ibu Hamil}

Diagram 5.3 Distribusi Frekuensi Pendidikan di Wilayah Kerja Puskesmas Sindang Jaya Kabupaten Tangerang $(n=10)$

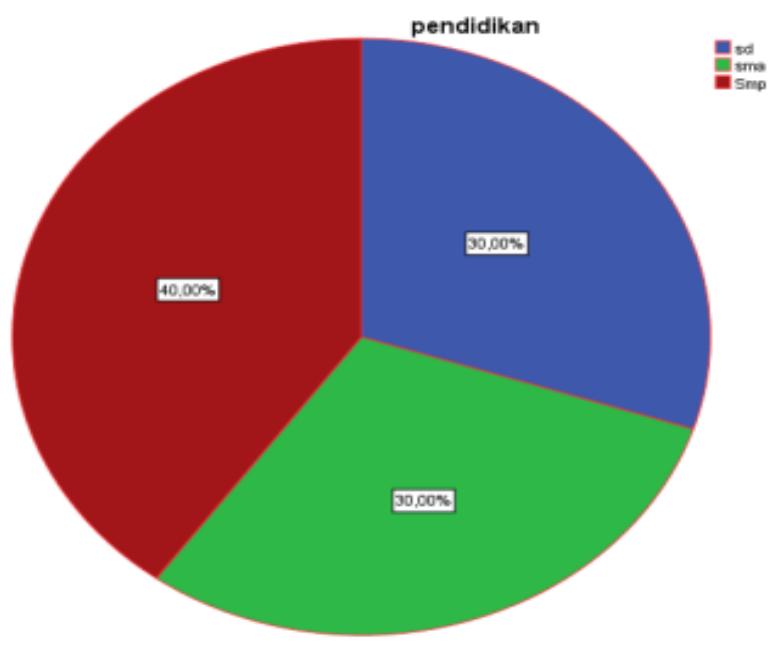


Berdasarkan diagram 5.3 yaitu distribusi frekuensi berdasarkan pendidikan sebanyak 10 responden ibu hamil yang berada di Wilayah Kerja Puskesmas Sindang Jaya Kabupaten Tangerang pendidikan Sd sebanyak 4 orang (40\%), sedangkan pendidikan Smp sebanyak 3 orang $(30 \%)$ dan pendidikan Sma orang 3 responden $(30 \%)$.

\section{4)Kadar Hemoglobin sebelum diberikan Buah Naga}

Tabel 5.1 Distribusi Frekuensi Kadar HemoglobinSebelum Diberikan Buah Naga Di Puskesmas Sindang Jaya Kabupaten Tangerang $(n=10)$

\begin{tabular}{lllllll}
\hline Varibel & Kategori & N & \% & Mean & Min & Max \\
\hline Kadar Hemoglobin & Normal & - & $0 \%$ & 10,030 & 9,0 & 10,8 \\
sebelum diberikan & Anemia & 10 & $100 \%$ & & \\
Buah Naga & $\begin{array}{l}\text { Ringan } \\
\text { Anemia Berat }\end{array}$ & - & $0 \%$ & & \\
& & 10 & 100 & & \\
\hline
\end{tabular}

Berdasarkan tabel 5.1 mengenai Ringan yaitu sebanyak 10 responden distribusi frekuensi berdasarkan kadar (100\%), dan dengan nilai kadar Hemoglobin sebelum pemberiakan Hemoglobin minimum 9,0 mg/dl dan Buah Naga, dari 10 responden maximum $10,8 \mathrm{mg} / \mathrm{dl}$ dengan rata-rata menunjukkan bahwa seluruh kadar Hemoglobin 10,030 mg/dl. responden dengan kategori Anemia

\section{5)Kadar Hemoglobin setelah diberikan Buah Naga}

Tabel 5.2 Distribusi Frekuensi Kadar Hemoglobin Setelah Pemberian Buah Naga Di Wilayah Kerja Puskesmas Sindang Jaya Kabupaten Tangerang $(\mathrm{n}=10)$

\begin{tabular}{|c|c|c|c|c|c|c|}
\hline Variabel & Kategori & $\mathbf{N}$ & $\%$ & Mean & Min & Max \\
\hline Kadar Hemoglobin & Normal & 7 & $70,0 \%$ & 11,140 & 10,0 & 12,0 \\
\hline setelah diberikan & Anemia & 3 & $30,0 \%$ & & & \\
\hline \multirow[t]{4}{*}{ Buah Naga } & Ringan & & & & & \\
\hline & Anemia & - & $0 \%$ & & & \\
\hline & Berat & & & & & \\
\hline & & 10 & 100 & & & \\
\hline
\end{tabular}


Berdasarkan tabel 5.2 mengenai distribusi frekuensi berdasarkan kadar Hemoglobin setelah pemberian Buah Naga, dari 10 responden menunjukkan bahwa lebih dari setengahnya responden dengan kategori normal yaitu sebanyak 7 responden $(70,0 \%)$, dan sebagiankecil responden dengan kategori hamper setengahnya 3 responden $(30,0 \%)$. Dengan nilai kadar Hemoglobin minimum 10,0 $\mathrm{mg} / \mathrm{dl}$ dan maximum $12,0 \mathrm{mg} / \mathrm{dl}$ dengan rata-rata kadar Hemoglobin $11,140 \mathrm{mg} / \mathrm{dl}$.

\section{Analisa Bivariat}

Analisa bivariate adalah analisi yang akan menjelaskan adakah Pengaruh Pemberian Buah Naga Terhadap Peningkatan Kadar Hemoglobin DiPuskesmas Sindang Jaya Kabupaten Tangerang, oleh karena itu dilakukan analisa bivariate untuk mengetahui pengaruh antara kedua variabel tersebut, data penelitian dilakukan dengan menggunakan uji statistic dengan uji willcoxon test.

Tabel 5.3 Pengaruh Pemberian Buah Naga Terhadap Peningkatan Kadar Hemoglobin Pada Ibu Hamil Di Puskesmas Sindang Jaya Kabupaten Tangerang $(n=10)$

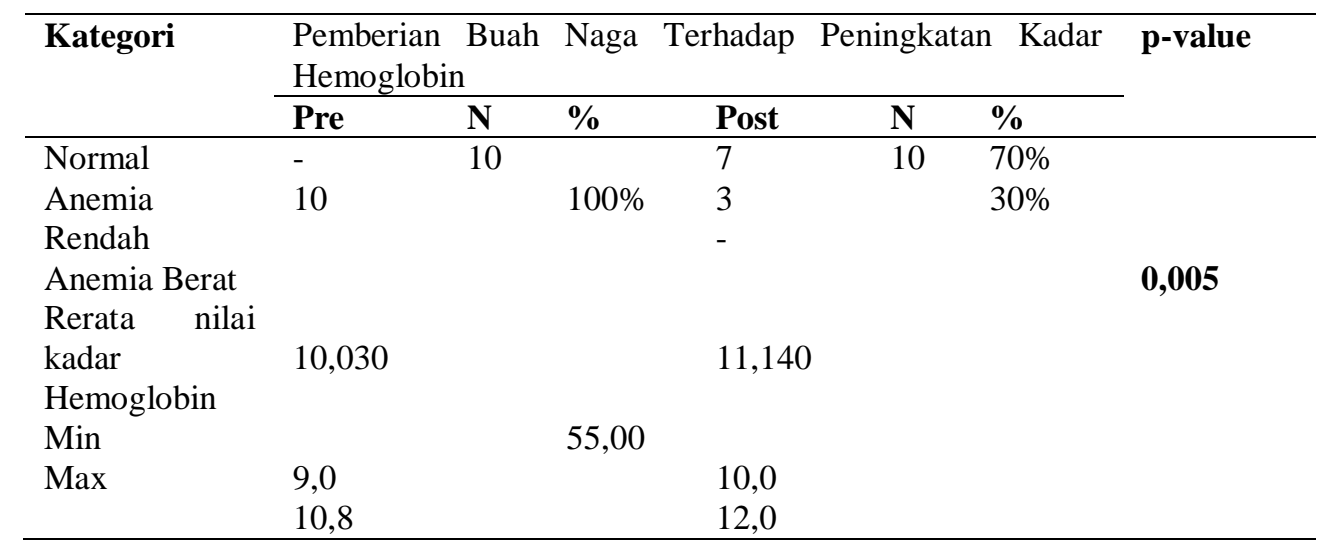

Berdasarkan tabel 5.3 dapat diketahui nilai kadar Hemoglobin sebelum diberikan Buah Naga dari 10 responden, terdapat 10 responden $(100,0 \%)$ yang berada dikategori Anemia Ringan, dengan nilai minimum 9,0 $\mathrm{mg} / \mathrm{dl}$ dan maximum yaitu 10,8 mg/dl dengan rerata nilai kadar
Hemoglobin 10,030 mg/dl yang berarti termasuk dalam kategori Hemoglobin Anemia Ringan sedangkan setelah diberikan Buah Naga dari 10 responden terdapat 7 responden $(70,0 \%)$ yang kadar Hemoglobinnya berada dikategori normal dan 3 responden $(30,0 \%)$ yang kadar 
Hemoglobinnya masih berada dikategori Anemia Ringan dengan nilai minimum $10,0 \mathrm{mg} / \mathrm{dl}$ dan maximum $12,0 \mathrm{mg} / \mathrm{dl}$ dengan rerata nilai kadar Hemoglobin $11,140 \mathrm{mg} / \mathrm{dl}$ yang berarti termasuk kedalam kategori Anemia Ringan. Berdasarkan uji willcoxon, didapatkan bahwa terdapat adanya pengaruh Buah Naga terhadap penurunan kadar Hemoglobin sebelum dan setelah diberikan Buah Naga, dengan nilai p-value $0,005<\mathrm{a}(0,05)$.

\section{PEMBAHASAN}

Berdasarkan hasil penelitian yang diperoleh, maka penelitian memproleh data yang merupakan keadan nyata dengan cara memberikan buah naga kepada 10 responden untuk mengetahui Pengaruh Pemberian Buah Naga Terhadap Peningkatan Kadar Hemoglobin Pada Ibu Hamil Dipuskesmas Sindang Jaya Kabupaten Tangerang. Data tersebut dijadikan tolak ukur dalam melakukan pembahasan sebagai hasil akhir dapat dijabarkan sebagai berikut:

\section{Analisa Univariat}

\section{a. Bedasarkan Usia Ibu Hamil}

Berdasarkan diagram 5.1 diatas 10 responden dengan presentase $(60 \%)$ berusia 18-22 tahun yang mengalami anemia rendah dan presentase $(30 \%)$ berusia 33-37 yang mengalami anemia rendah sedangkan 1 orang (10\%) berusia 23-27 yang mengalami anemia rendah.

Dari hasil analisa tersebut peneliti dapat menyimpulkan bahwa 10 responden dengan presentase (60\%) berusia 18-22 tahun yang mengalami anemia rendah dan presentase (30\%) berusia 33-37 yang mengalami anemia rendah sedangkan 1 orang (10\%) berusia 23-27 yang mengalami anemia rendah hal ini disebabkan karena kehamilan dibawah usia 20 tahun dapat menimbulkan banyak permasalahan karena bisa mempengaruhi organ tubuh seperti rahim, bahkan bayi bisa prematur dan berat lahir kurang. Hal ini disebabkan karena wanita yang hamil muda belum bisa memberikan suplai makanan dengan baik dari tubuhnya ke janin di dalam rahimnya (Marmi,2012

\section{b. Berdasarkan Usia Kehamilan}

Berdasarkan diagram 5.2 diatas sebagian besar usia kehamilan trimester I berjumlah 4 orang (40\%), yang mengalami usia kehamilan pada trimester II berjumlah 4 orang (40\%), sedangkan usia kehamilan pada trimester III berjumlah 2 orang (20\%). 
Anemia dalam kehamilan merupakan kondisi ibu dengan kadar haemoglobin $(\mathrm{Hb})$ dalam darahnya kurang dari 12 gr\% (Winkjosastro, 2002). Sedangkan anemia dalam kehamilan merupakan kondisi ibu dengan kadar haemoglobin dibawah $11 \mathrm{gr} \%$ pada trimester I dan III atau kadar $<10,5$ gr\% pada trimester II, nilai bats tersebut dan perbedaannya dengan kondisi wanita tidak hamil, terjadi karena hemodulasi, terutama pada trimester II (Wahyuni,2009).

\section{c. Berdasarkan Pendidikan}

Berdasarkan diagram 5.3 diatas Hasil penelitian ini didapatkan 4 responden (40\%) sebagian besar SD sedangkan Smp dan Sma masing-masing 3 responden yaitu $(30 \%)$

Menurut Budiono, 2009 Pendidikan yang dijalani seseorang memiliki pengaruh pada peningkatan kemampuan berpikir, dengan kata lain seseorang yang berpendidikan lebih tinggi akan dapat mengambil keputusan yang lebih rasional, umumnya terbuka untuk menerima perubahan atau hal baru dibandingkan dengan individu yang berpendidikan ibu hamil yang rendah mempengaruhi informasi sehingga pengetahuan tentang anemia dan faktor-faktor yang berhubungan dengannya menjadi terbatas, terutama pengetahuan tentang zat besi.

\section{d. Kadar Hemoglobin sebelum pemberian Buah Naga}

Berdasarkan penelitian yang didapatkan bahwa sebelum diberiakan Buah Naga, dari 10 responden menunjukkan bahwa seluruh responden dengan kategori Anemia Ringan yaitu sebanyak 10 responden $(100 \%)$, dan dengan nilai kadar Hemoglobin minimum 9,0 $\mathrm{mg} / \mathrm{dl}$ dan maximum 10,8 mg/dl dengan rata-rata kadar kolesterol $10,030 \mathrm{mg} / \mathrm{dl}$.

Anemia merupakan penurunan jumlah masa eritrosit (red cell mass), sehingga darah tidak dapat memenuhi fungsinya untuk membawa oksigen dalam jumlah yang cukup ke jaringan perifer.Secara praktis, anemia ditunjukkan oleh perubahan hemoglobin, hematokrit dan hitung eritrosit. Tetapi yang paling lazim dipakai adalah kadar hemoglobin dan hematokrit (Maulina,2015, Ulya, 2018).

Anemia pada kehamilan tidak dapat dipisahkan dengan perubahan 
fisiologis yang terjadi selama proses kehamilan, umur janin, dan kondisi ibu hamil sebelumnya. Pada saat hamil, tubuh akan mengalami perubahan yang signifikan, jumlah darah dalam tubuh meningkat sekitar 20 - $30 \%$, sehingga memerlukan peningkatan kebutuhan pasukan besi dan vitamin untuk membuat hemoglobin $(\mathrm{Hb})$. Saat hamil, tubuh ibu akan membuat lebih banyak darah untuk berbagi dengan bayinya. Tubuh memerlukan darah hingga $30 \%$ lebih banyak dari pada sebelum hamil (Noverstiti, 2012, Astriana,2017).

\section{e. Kadar Hemoglobin setelah pemberian Buah Naga}

Berdasarkan hasil penelitian didapatkan bahwa kadar Hemoglobin setelah pemberian Buah Naga, dari 10 responden menunjukkan bahwa lebih dari setengahnya responden dengan kategori normal yaitu sebanyak 7 responden $(70,0 \%)$, dan sebagian kecil responden dengan kategori hamper setengahnya 3 responden $(30,0 \%)$. Dengan nilai kadar Hemoglobin minimum 10,0 mg/dl dan maximum 12,0 $\mathrm{mg} / \mathrm{dl}$ dengan rata-rata kadar kolesterol 11,140 $\mathrm{mg} / \mathrm{dl}$.
Menurut Himagropertanian, 2012)

Buah naga memiliki khasiat untuk kesehatan manusia, buah naga mempunyai kandungan gizi seperti vitamin $\mathrm{C}$, vitamin $\mathrm{B} 3$, vitamin $\mathrm{B} 1$, vitamin B2, zat besi , fosfor, dan serat. Buah naga diantaranya sebagai penyeimbang kadar gula darah, membersihkan darah, menguatkan ginjal, menyehatkan lever, perawatan kecantikan, menguatkan daya kerja otak, meningkatkan ketajaman mata, mengurangi keluhan panas dalam, menstabilkan tekanan darah, mencegah sembelit dan memperlancar feses, pencegah kanker usus, pelindung kesehatan mulut, serta pengurang kolestrol, pencegah pendarahan, dan obat keluhan keputihan. Adanya khasiatkhasiat tersebut disebabkan oleh kandungan nutrisi dalam buahnya yang sangat mendukung kesehatan manusia.

Penelitian yang dilakukan oleh Thamrin 2018 dengan judul Buah Naga (Hylocereys Polyrhizus) Meningkatkan Kadar Hemoglobin Pada Remaja Putri. Menunjukan bahwa ada peningkatan kadar hemoglobin pada kelompok intervensi dibandingkan kelompok 
kontrol. Pretest dan posttest pada kelompok intervensi sebesar $9,15 \%$ tinggi dibandingkan kelompok kontrol sebesar 4,6\%. Pretest dan protest II pada kelompok intervensi sebesar 10,44\% lebih tinggi dibanding kelompok-kelompok kontrol sebesar 5,7\%. Peningkatan kadar hemoglobin yang tertinggi terjadi pada pretest dan posttest III pada kelompok intervensi sebesar $10,86 \%$ lebih tinggi disbanding kelompok kontrol sebesar $10,12 \%$. Pretest dan posttest IV terjadi penurunan kadar hemoglobin pada kelompok intervensi sebesar 4,46\% lebih rendah setelah intervensi dibandingkan pada kelompok kontrol sebesar $5,12 \%$.

Sedangkan penelitian yang dilakukan oleh Bariah 2018 dengan judul Pengaruh Perbedaan Suplemen Jus Jambu Merah Dengan Jus Buah Naga Merah Untuk Meningkatkan Kadar Hemoglobin Dan Hematokrit Pada Ibu Postpartum Dengan Anemia menunjukan bahwa kadar hemoglobin pada kelompok intervensi 1 sebelum intervensi ratarata $27.9 \%$ sedangkan sesudah intervensi 38,9\% dan selisih 11,04\% pada kelompok intervensi 2 sebelum sebelum intervensi rata-rata $28,0 \%$ sedangkan sesudah intervensi $35,6 \%$ dan selisih 7,63\%.

Dalam penelitian ini yang dilakukan selama 5 Hari didapatkan hasil adanya peningkatan kadar Hemoglobin Dipuskesmas Sindang Jaya Kabupaten Tangerang dengan penambahan Buah Naga 1 hari sekali sebanyak 250 gr. Rata-rata hasil yang didapat menempati kategori normal $(11,140 \mathrm{mg} / \mathrm{dl})$,

\section{KESIMPULAN}

Setelah melakukan penelitian tentang Pengaruh Pemberian Buah Naga Terhadap Kadar Hemoglobin Pada Ibu Hamil Di Puksesmas Sindang Jaya Kabupaten Tangerang Tahun 2019. Maka peneliti dapat mengambil kesimpulan sebagai berikut:

a. Teridentifikasi hasil penelitian sebelum mengkonsumsi buah naga terdapat 10 responden $100 \%$ yang menderita kadar hemoglobin rendah

b. Teridentifikasi hasil penelitian Setelah mengkonsumsi buah naga secara keseluruhan mengalami penaikan sebanyak 7 responden (70\%) dan 3 responden yang mengalami anemia rendah 
c. Teridentifikasi hasil penelitian dari hasil uji willcoxon test mengenai analisa pengaruh pemberian buah naga pada ibu hamil terdapat bahwa nilai p-value $0,005<a(0,05)$ sehingga dapat disimpulkan ada pengaruh yang

\section{DAFTAR PUSTAKA}

Adriana Meryana. 2012 “ Penagntar Gizi Masyarakat “. Jl. Tambra Raya No 23 Rawamangun . Jakarta 13220.

Agustin Nelly. 2009. “ Hubungan Anemia Pada Ibu Hamil Dengan Kejadian Bayi Berat Lahir Rendah ". Universitas Indonesia.

Anggeraini Dwi Putri. 2018. " Faktorfaktor Yang Mempengaruhi Remaja Dengan Buah Bit Anemia Pada Ibu Hamil “. Universitas Muhammadyah.

Astrianna Willy. 2017 “ Kejadian Anemia Pada Ibu Hamil Ditinjau Dari Paritas Dan Usia". STIKES Al-Ma'arif Baturaja.

Bariah dkk. 2018. "Pengaruh Perbedaan Suplemen Jus Jambu Merah Dengan Jus Buah Naga Merah Untuk Meningkatkan Kadar Hemoglobin Dan Hematokrit Pada Ibu Postpartum Dengan Anemia ".Politeknik Medica Farma Husada. Mataram.

Evelyn. 2009 “ Anatomi dan Fisiologis untuk Pramedi". Pt Gramedia, Jakarta. signifikan antara Pemberian Buah Naga Dengan Peningkatan kadar Hemoglobin Pada ibu Hamil Di Puskesmas Sindang Jaya Kabupaten Tangerang.

Fitrian dkk. 2017. “ Pengaruh Pemberian Jus Jambu Biji Terhadap Kadar HB Pada Ibu Hamil Timester III". STIKes Ganesha Husada Kediri.

Helmi dkk. 2012. “ Pengaruh Pemberian Jus Buah Naga Terhadap Jumlah Hemoglobin Eritrosit Dan Hematokrin Pada Mencit Putih Betina ".STIFARM. Padang.

Hidayat , A.A.A. 2013 " Metode Penelitian Keperawatan Dan Teknik AnalisaData "Jakarta : Salemba.

Hilda dkk. 2018. “ Buah Naga Meningkatkan Kadar Hemoglobin Pada Remaja Putri “.Universitas Muslim Indonesia.

Ikwati dkk. 2018. "Pengaruh Buah Bit Terhadap Indek Eritosit Pada Remaja Putri Dengan Anemia". Akademi Analis Farmasi Semarang.

Notoatmodjo Soekidjo. 2012 “ Metode Penelitian Kesehatan ".Jakarta : Rineka

Nurheti Yulianti. 2017. "The Miracle Of Colors Keajaiban Buah Dan 
Sayur “. JL. Beo 34-40 Yogyakarta.

Profil Kesehatan Banten 2013 www.depkes.go.id/hasil\%20Ris kesdas(22 Maret 2019)

Sugiono . 2014. “ Metode Penelitian KuantitatifDan $R \& D$ “. Alfabet, $\mathrm{CV}$. Bandung.

Swarjana Ketut I. 2016." Statistik Kesehatan ".Yogyakarta.

Widarsah dkk. 2013 " Anemia Ibu Hamil Trimester II\&II Meningkatkan Resiko Kejadian Berat Badan Bayi Lahir Rendah “. Universitas Udayana.
Ulya Syahidatul. 2018. “ Pengaruh Pemberian Ekstra Daging Buah Kurma Terhadap Kadar Hemoglobin Pada Mencit Bunting ".UIN Sunan AmpelSurabaya.

Wahyuni Ningrum. 2009 "Pemberian Tablet Fe Pada Ibu Hamil Untuk Mencegah Anemia” http://ningrumwahyuni.wordpre s.com/2009/(22 Maret 2019) 